\title{
CORRESPONDENCE
}

\author{
THE LUXEMBOURG COLLOQUIUM-A REPLY
}

SIR,-I fear Dr. Miller has misunderstood the purpose of my paper which was to report on the Luxembourg deliberations and to compare the basis of classification with schemes such as those proposed by Arkell (1946) and the Copenhagen Sub-committee (1961). Many of the points to which he takes exception are either quotations or paraphrases of material from one or other of these sources. My intention was to present an objective appraisal, though a certain personal bias was inevitable from one who has been concerned with these problems for many years.

In accepting these limitations I was denied the freedom that Dr. Miller claimed when he "prefer(red) ... to disregard the Copenhagen Rules", but this was no bad thing. The virtue of the Luxembourg Colloquium lay in the opportunity it gave for re-assessing our ideas on the Jurassic in an international environment, for clearing away dead wood from the past and for seeking compromise solutions in the light of present knowledge. This background rather than my own opinions was the subject of my paper.

As for the Uppermost Jurassic problem, I went to Luxembourg believing that the situation described by Arkell in 1956 still obtained-that is, that no trans-European objective correlation could be made above the horizon of the Gravesia Zone. At the colloquium I was told by Drs. Barthel and Zeiss of Erlangen that correlation between England, parts of France, and Bavaria was possible at the level of the Albani Zone, suggesting that the base of the Portlandian (sensu anglico) was an important datum. However, with Casey's work on the British faunas assignable to both Volgian stages and particularly his recognition of a common base to the Cretaceous in England and Russia, there is no longer a case for dual standards. Whatever its name we should now be prepared to recognize in this country a unit (or units) of post-Autissiodorensis Zone-pre-Cinder Bed age.

Finally, Dr. Miller's dicta on the concept of zones (with which I disagree) have caused me to clarify my own ideas on the subject. I look forward to reading his full account.

\footnotetext{
Department of Geology,

UNIVERSITY COLLEGE, LONDON, W.C. 1.

4th December, 1964.
}

A. J. LLoyd.

\section{THE MALVERN LINE}

Sir,--In their recent paper Phipps and Reeves (1964) reopen discussion on the Malvern line. In it they are particularly critical of the conclusions drawn by Reading and Poole (1961 and 1962) from an exposure in the Gullet Quarry, where the contact between the Upper Llandovery and Pre-Cambrian is interpreted by the latter authors as an unconformity. Another exposure at the "sycamore tree locality" is interpreted similarly. Phipps and Reeves contend that the junction is a tectonic one; a conclusion supported by Whitworth (1962). Among the arguments presented by Phipps and Reeves in support of their conclusions, they discuss the sedimentary environment of the period in that area, concluding that current velocities were insufficient to transport the large boulders found at the contact. Ziegler (1964), however, adds supporting palaeontological evidence to Reading and Poole's thesis and demonstrates that the Upper Llandovery deposits of the Gullet are younger than those immediately to the west of the Malvern Range. He further suggests that a fault-controlled scarp was transgressed by the late Upper Llandovery sea causing these deposits to rest directly upon Malvernian, and that these controlling faults, trending north-south, are early manifestations of the Malvern axis. 